\section{Connecting and Reconnecting: Outfitting the Figure of the Cyborg for Transnational Coalition-building}

\author{
Jessica E. Brophy \\ Bridgewater College, USA
}

\author{
KOME - An International Journal of Pure \\ Communication Inquiry \\ Volume 4 Issue 2, p. 17-27. \\ (C) The Author(s) 2016 \\ Reprints and Permission: \\ kome@komejournal.com \\ Published by the Hungarian Communication \\ Studies Association \\ DOI: 10.17646/KOME.2016.22
}

\begin{abstract}
This work attempts to rehabilitate Donna Haraway's (1991) figure of the cyborg to increase the possibilities of alliances between transnational feminism and cyborg or technoscience feminism. Haraway's cyborg offers little impetus for political investment and coalition building. This work develops an optional prosthesis of responseability for the cyborg figuration, one that enables the cyborg to invest locally. This ethic of response-ability is developed via the work of Mary Strine (1989), Adrienne Rich (1984) and Aimee Carillo Rowe (2005). This supplementary ethic grafts a "collectivist conscience" onto the permeable being of the cyborg, encouraging alliance- and coalitionbuilding.
\end{abstract}

Keywords: cyborg, Haraway, transnational feminism, response-ability, coalition-building, feminist theory

At a certain point, a woman writing this poem, has had to reckon the power of poetry as distinct from the power of the nuclear bomb, of the radioactive lessons of her planet, the power of poverty to reduce people to spectators of distantly conjured events. She can't remain a spectator. Adrienne Rich, What is Found There, p. 89 


\section{Introduction}

This essay is an exploration of the possibilities for an ethic of coalition building found in the figure of the cyborg in poststructuralist feminist theory. Poststructuralist figurations such as Donna Haraway's (1991) cyborg or Rosi Braidotti's (1994) nomad offer alternative ways of understanding the self and its relation to the world - ways that do not encourage or demand the erasure of difference. However, such figurations' rejection of indebtedness and obligation can encourage the development of seductively singular and individually focused platforms of (in)action; that is, these figures offer little impetus or direction for coalition- or alliancebuilding with other individuals or groups, and insufficiently encourage political investment. The development of "transnational technoscience studies" (Haraway, 1999, p.357) coupled with the figure of the cyborg has limited potential to engage with both feminists of the Global South and in transnational feminist alliances.

There remains an often-lamented gap between theory and action in contemporary feminisms; while many feminist theorists might live a politically engaged life, such engagement is not necessitated or encouraged by the theory itself. Evidence of this is clear in poststructuralist figures such as the cyborg. In this essay, I offer a supplementary ethic for the cyborg, grafting a means to access a "collectivist conscience" onto the permeable being of the cyborg. This ethic remains an optional prosthesis for the cyborg, maintaining the cyborg's rejection of organic wholeness while furthering its potential for meaningful coalition and collaboration.

This essay will locate the cyborg figuration as an exemplar of poststructuralist attempts to initiate alternative knowledge forms. I briefly explore the discursive and epistemic possibilities encouraged by Haraway's (1991) cyborg, with particular attention given to the ways in which Haraway denies the cyborg as beholden, obligated or indebted. This constructs the cyborg as a figure that is seductive in its singularity and its individualism. In hopes of encouraging use of the cyborg figure as a means for building transnational feminist alliances in our contemporary technologically-driven culture, I develop an ethic of response-ability via the work of Strine (1989), Rich (1984) and Rowe (2005).

The essay then draws connections between transnational feminism and the ethic of responseability. Transnational feminism draws on postcolonial discourses, and meshes in effective and nuanced ways with poststructuralist theories while maintaining the importance and force of embodied experience and political efficacy, particularly through the concepts of the local and the complexities of mobility and globalization. This contrasts with the figure of the cyborg, which is notably "placeless" and "ahistorical"; i.e. it does not have its own "local." Finally, the essay closes with a brief discussion of why feminist theorists might desire the attachment and engagement demanded by an ethic of response-ability and how this ethic may further the theoretical potential and political efficacy of the cyborg figure.

\section{Rejecting structuralism and essentialism}

Theorists enact poststructuralism in as many forms as feminism itself and poststructuralist feminisms are similarly varied; however, a key principle is theorizing subjectivity. Chris Weedon (1997) calls poststructuralist feminism a form of "knowledge production" (p. 40), or a way to attend to the multiple forces of power and to identify and develop alternatives to extant (or historical) practices. Poststructuralists struggle to understand the subject as neither a simple reflection of outside forces, nor as an autonomous liberal subject devoid of exterior influence, but rather as "precarious, contradictory and in process, constantly being constituted in discourse each time we think or speak" (Weedon, 1997, p. 32). 
This process is happening in light of what Braidotti terms the "crisis and decline of the classical system of representation of the subject, in the political, epistemological, and ethical sense of the term" (1994, p. 96). Many poststructuralist feminists see the rejection of essentialism and the upset of hegemonic narratives as a positive trend full of potentialities rather than a 'crisis.' Certainly Braidotti casts the challenges to the classical system of representation as creating new spaces for "alternative values to be postulated" (1994, p. 96). The poststructuralist project, similar to the project of feminist theory, is about re-envisioning what counts as knowledge and how knowledge is produced, consumed and circulated (see Hicks, 1990). If knowledge is partial and situated, as theorists such as Haraway (2008, 1995, 1991) argue, interrogating the production of those situated knowledges is a key element of the "theoretical genealogy ... and feminist intellectual tradition" (Braidotti, 1994, p. 276). It is a proactive project rather than reactive critique, and subjectivity is a central node of that intellectual endeavor.

Poststructuralist theorists have taken up the question of subjectivity in various ways: Foucault's $(1972,1980)$ works emphasize the power relations of language and discourse; Butler (1990) has raised questions of performativity in relation to subjectivity and Braidotti's (1994) "nomad ethics" emphasize the processes of becoming in relation to the subject. All these "alternative" forms of subjectivity acknowledge the multiple forces, identities, locations and objects that affect our lived experience. Many feminist poststructuralists attempt to navigate the complex iterations of the self-world (inter)relationship in ways that preserve differences among individuals, build coalitions and challenge (patriarchal) norms.

\section{Poststructuralist figurations}

Often these theorists develop what Braidotti (1994) calls figurations through which to interrogate the incredibly complex (inter)relationships of individuals, groups, knowledge and power, and to highlight the possibilities of alternatives. ${ }^{1}$ In her introduction to Nomadic Subjects, Braidotti writes, "a figuration is a politically informed account of an alternative subjectivity. I feel a real urgency to elaborate alternative accounts, to learn to think differently about the subject, to invent new frameworks, new images, new modes of thought" $(1994$, p. 1). While Braidotti credits Gilles Deleuze with the development of the figuration of the rhizome and its impact on her own figuration of the nomad, Haraway (2008) specifically cites figures as a way to "grapple" with the tensions between the material and story, narrative and myth:

Figures help me grapple inside the flesh of mortal world-making entanglements that I call contact zones... Figures collect the people through their invitation to inhabit the corporeal story told in their lineaments. Figures are not representations or didactic illustrations, but rather material-semiotic nodes or knots in which diverse bodies and meanings coshape one another. For me, figures have always been where the biological and literary or artistic come together with all of the force of lived reality (p. 15).

\footnotetext{
${ }^{1}$ N. Katharine Hayles (1999) offers the idea of "constellations" rather than figurations. Constellations are more clearly historically located, but also connote the nuanced and complex myriad of relationships at stake in any exploration of the self-world relationship and attendant concepts. Hayles' concept of constellations also preserves the dynamism of such ways of thinking about the world. As she writes, the formation of a constellation "marks the beginning of a period; its disassembly and reconstruction signal the transitioning to a different period... Rarely is a constellation discarded wholesale. Rather, some of the ideas composing it are discarded, others are modified, and new ones are introduced. Like the attributes composing and artifact, the ideas in a constellation change in a patchwork pattern of old and new" (p. 15).
} 
This is especially significant given the commitment to materiality of Haraway's figure of the cyborg, as we examine later. Haraway's emphasis on the corporeality of the story lends credence to the cyborg as an organizing figure for alliances with transnational and postcolonial feminists. Haraway's insistence on the figure as having a physical and material reality parallels with the actualities of the postindustrial, globalized world-i.e., that there are hegemonic and colonial narratives, myths and stories that have very real physical and material consequences.

Braidotti intimates that poststructural figurations offer alternatives to specific current/contemporary concepts - such as the autonomous liberal subject. That is, figurations are tied to a specific historical moment with its attendant social and political issues and therefore do not express some totalizing or universal Truth, but rather engage with a particular project in a particular way. Thus, a project like Haraway's cyborg is neither "timeless" nor "universally applicable" - it needs "updating" and "outfitting" to address a new moment with its own social and political issues.

Why update and outfit the cyborg, in particular? Are there not many such figures and figurations, constellations of concepts to further the feminist intellectual tradition? Haraway developed the figure of the cyborg in 1991, in the days of the nascent Internet, as a figure to challenge some feminist theorists' efforts to unify feminism in a way Haraway found damaging to the preservation of specificity and difference. Haraway also wanted to rescue/liberate/steal the cyborg - that human-machine entity borne of the military-industrial complex - from sole patriarchal proprietorship. In doing so, Haraway constructed a figure confounding and challenging boundaries, one that represents the multiple tensions of technology in a way that remains relevant today. While our technologies have changed, the information society become more pronounced and the world increasingly globalized, the fundamental tensions represented in the figure of the cyborg persist. If anything, the realities of living in a highly technical, global, post-industrial capitalist society lend themselves more readily to the cyborg than the gloried, Utopian days of the early Internet and the .com boom times.

Haraway's cyborg has much to offer feminist theorists today; it remains a potent figure for alliance-building with transnational and postcolonial feminists in light of the transition of the "white capitalist patriarchy...into the domination by information technology" which has "cannibalized" women and pushed them from "the field of visible social agents" (Braidotti, 1994, p. 104). While the potential relationships between cyborg technofeminisms and transnational feminisms will be explored in more detail later, both share the goal of "shifting the focus of feminist critique [to offer] us a new set of lenses with a better chance of rendering the hitherto-invisible visible" (Yeoh, 2005, p. 62).

\section{The cyborg}

Haraway (1991) begins her (in)famous essay on the cyborg with an irreverent expression of her own desires in relation to the project at hand. She formulates her position as "blasphemous," which guards against moral compulsion, while still preserving the need for community - for Haraway, blasphemy is "not apostasy" (p. 149). In other words, Haraway is interested in constructing a figure that offers an alternative not only to a "traditional" understanding of the self-world relationship, but an "ironic political myth" (p. 149) that challenges from within the frameworks of feminism, socialism and materialism as well. A primary irony of the cyborg is its existence as a product of the military-industrial complex: its tightly woven history with violence, capitalism and informatics.

For Haraway, then, her first and boldest move with the cyborg is one of disassociation. That is, Haraway positions the cyborg as already extant as myth and reality and then proceeds to sever the figure from its socio-historical ties. Historically, the line between organic and 
manufactured has been marked as impermeable and hierarchical - with that which is constructed privileged over the organic. Haraway (1991) argues "for pleasure in the confusion of [such] boundaries and for responsibility in their construction" (p. 150, emphasis in original). Haraway develops the cyborg figure as a means to debunk the narrative of technology as progressive, androcentric, and tied to the military-industrial complex. Simultaneously, Haraway's cyborg is an attempt to side step the historical baggage and contemporary debate surrounding sexual difference without abandoning materialism. The cyborg has no interest in "seductions to organic wholeness through a final appropriation of all the powers of the parts into a higher unity" (p. 150). This is one of the tenets of the cyborg as a construct: a dedication to unfinished-ness. While the cyborg can seek new connections, new technologies, new parts to be configured resulting in various degrees of success, it is never complete. To be complete is to be fixed, named, united and unified; to be complete is to capitulate to the very arguments for organic wholeness Haraway tapped the cyborg to confound.

To debunk this narrative of technology and side step the debate of sexual difference, Haraway rejects a long "laundry list" of theoretical "debts." For instance, she says the cyborg has no origin story because an origin story depends on original unity and identification with nature, which she denies the cyborg. This itself can raise objection, since theorists such as $\mathrm{N}$. Katharine Hayles (1999) view science as highly imbued with a "grand narrative" of progress (see Lyotard, The Postmodern Condition, 1989), which posits or necessitates an origin and conceivably also an end point. We must also question whether Haraway's attempts to sever the cyborg from its origin story are successful, and if they are, what problems the success causes. If the cyborg's radical break from its own lineage is complete, then theorists employing the cyborg need not acknowledge the cyborg's patriarchal, capitalistic roots. Maintaining awareness of those roots, questioning what assumptions and meanings the cyborg packs, is key to producing intellectually honest theory. We cannot attempt theoretical coalitions between technofeminisms and transnational feminisms without acknowledging the uneven application of technology, its patriarchal and capitalist roots, and its exploitive realities. Yet, Haraway's initial efforts to sever the cyborg are not without value.

In a sweeping paragraph, Haraway positions the cyborg as existing beyond the desire for wholeness, and as standing outside all dualisms. She denies the cyborg's lineage, marking the figure as often "unfaithful" to both militarism and patriarchal capitalism. In this, she repositions the cyborg as not belonging necessarily to that lineage. This allows the cyborg to take up new causes and head in new directions; it frees the cyborg to be a potential vehicle for feminist theory and work. Haraway locates the cyborg as a figure "resolutely committed to partiality" while simultaneously "needy for connection" (p. 151). Haraway argues the figure's "wariness" of holism and traditional (organic) models of community does not negate the figure's desire for or ability to connect. This allows for the possibility of political engagement and collaboration, though does not necessitate or even encourage it.

Haraway's opening arguments are necessary for the figure of the cyborg to inhabit the space of an alternative poststructuralist narrative (see Weedon, 1999). These moves are simultaneously the strength of the cyborg figure in technofeminism and a question of its usefulness as a feminist poststructuralist figuration. That is, despite Haraway's repeated insistence on the cyborg's political potential for engagement, the moves required to create the figuration of the cyborg limit its viability in terms of political efficacy.

Haraway's overview of the "fracturing" of feminism via the rise of identity politics again articulates her desire to reject what she terms the "natural matrix of unity." She offers a stinging, though oversimplified, review of Catherine MacKinnon's version of radical feminism, which Haraway calls "totalizing in the extreme" (p. 159). Though her rejection of this basis for political efficacy rightly preserves the differences between and among women, the rest of her construction never seems to recover from this radical rejection of indebtedness, 
history and community. Haraway arrives at an unnecessarily harsh conclusion: we should embrace the cyborg for its partiality, and (most) coalition-building feminisms overcome the fracturing of feminism through the erasure of difference and we should consider them warily, if at all. This drastically reduces the possible ways to build coalitions among feminists or other progressives. Though Haraway attempts to move beyond the cyborg's radical commitment to partiality, she cannot seem to get the purchase required for "reconstructing socialist-feminist politics" (p. 163).

Haraway parallels the cyborg's radical partiality and permeability with feminist thought of the Global South; however, her insistence on the "informatics of domination" does not sufficiently alleviate her erasure of transnational feminism's ties to the local and experiences of fractured mobilities. That is, though Haraway acknowledges the exploitation of women by/through a "world system of production/reproduction and communication" (p. 163), she does not seem to address the massive gap in technological access, the material and lived conditions in the Global South. The cyborg's placelessness fails to recognize the complexities of mobility and affective ties in the globalized world. Mobilities "no longer take the form of permanent ruptures, uprooting, and settlement, but are more likely to be transient and complex, ridden with disruptions, detours, multi-destinations, and founded in interconnections and multiple chains of movement" (Yeoh, 2005, p. 60). Haraway's desire to radically sever the cyborg from its history and present it as something neither human nor machine is not wholly successful. As Jasbir Puar argues, "Haraway's cyborgs are meant to undermine binaries - of humans and animals, of humans and machines, and of the organic and inorganic - a cyborg actually inhabits the intersection of body and technology" (p. 56). This line of reasoning, Puar continues, serves to reify both distinct categories-human and machine-rather than blur the boundaries between them.

However, the cyborg does press us to contemplate and complicate the boundary between human and machine, if not succeeding in its efforts to erase the categories. In this, the cyborg parallels the uneasy, dense positionality of those implicated in a globalized economy through and by technology. Just as "identities are multicausal, multidirectional, liminal" (Puar, 2012, p. 59) so are technologies, traditional flows of labor and culture become complicated by and through these technologies. If Haraway's figure of the cyborg attempts to sever itself from its origins in a way that may discount the complexities of that origin, how should transnational feminists ally themselves and their experiences to that of the cyborg? How can we build alliances if the cyborg figure radically disassociates with history and place (and the materiality of the local), both of which are important to transnational feminists?

\section{The limits of cyborg coalitions}

Feminist authors, including Haraway herself, have answered this question variously. If one contemplates her later writings on the cyborg $(1995,1999)$, it becomes clear that Haraway never envisaged the cyborg as lacking in opportunities for alliances and political efficacy. Indeed, she views her cyborg "story" as a "kind of truth [that] is situated and accountable, and therefore able to be in power-sensitive engagement with other versions and materializations of the world" (Haraway, 1995, p. xix). Thus, for Haraway the cyborg figure allows one to ally ones' self with (potentially) politically invested and efficacious O/others in a way that constitutes and reconstitutes "articulations of critical differences within and without each figure" (Haraway, 1999, p. 357). The cyborg's ahistorical and homeless mode of being, in this scenario, preserves differences but allows for alliances.

It is true that Haraway's cyborg figure does not preclude "power sensitive engagement." However, it is fair to say the cyborg figure's disassociation does not encourage such 
engagement. As Jenny Wolmark (1999) discusses, cyborg politics are based "on the possibility that new and strategic alliances can be forged between unexpected groups, no matter how partial or contradictory those alliances may be" (p. 4).

The problem with such partial or contradictory alliances is a lack of accountability, or affective investment over time to a specific place, community, group or individual. In fact, some theorists argue investment and affection by humans over time to a specific geographical entity creates 'place' (see Hay, 2006). If the cyborg figure's alliances are "new kinds of local, often temporary and shifting alliances" (Wolmark, 1999, p. 4), the cyborg figure operates in a different arena than its counterparts in such alliances. The cyborg, as a temporary figure, is able to engage in a way that may not recognize the stakes and realities for those entities. Likewise, because the figure is not required or encouraged to root itself and become affectively invested in communities, groups, places or causes, we cannot guarantee the outcome of such temporary alliances. That is, organizing the world and envisioning new subjectivities via the cyborg figure may enact a bankrupt subjectivity. If, in a cyborg world, we are not required to align our interests and desires with those we seek alliance with, and if we are not accountable for the consequences of our alliances then how desirable is the figure of the cyborg as a poststructuralist feminist figuration?

Jenny Sunden (2001) accurately notes that Haraway's attempts to maintain politically efficacious transnational coalitions in relation to the cyborg figure fail to acknowledge the realities of the technologies:

For Haraway, the telling of stories about technology has in itself a political potency and a capability to produce material changes... But to who are these textual tools of a cyborg feminist discourse accessible outside the inner circle of white, Western, middle-class cyborg feminists?...[Asking these questions] is a way to show that there might be a weak link between the feminist cyborg and the reality where women who use the new technology find themselves. (p. 217).

Sunden recognizes the shortcomings of the cyborg in terms of building coalitions, yet does not attempt to rehabilitate or re-work the figure to befit such coalition building. Sunden argues, "the politics of cyborgs are not to be found in collective, social movements, but are inextricably linked to their constantly moving borderland bodies" (p. 219). Sunden finds the cyborg best suited for other theoretical endeavors, accepting the theory/activism divide and placing the cyborg firmly in the realm of theory.

Unlike Sunden, Chela Sandoval $(1995,2000)$ refuses to accept the cyborg's limitations as a transnational coalition-building figure. Sandoval does much to rehabilitate the figure of the cyborg from many of Haraway's initial moves. Sandoval bases the cyborg's political efficacy on what she believes is understated yet potential in Haraway's figuration. Sandoval argues that a cyborg consciousness is merely another manifestation of the colonized consciousness. This advocated consciousness has not arrived with the advent of technology, but has existed in various forms in the colonized as a skill set "requisite for survival" (1995, p. 408).

Though Sandoval's (2000) text is somewhat over-eager, Methodology of the Oppressed offers constructs and critiques of interest to the project of rehabilitating the cyborg. First, Sandoval offers a well-developed analysis of the links among various horizontal metaphors of power. She marks the contemporary phenomenon of postmodern forms of power as a "globalized, flattened but mobile, grid-like terrain" (p. 74). This parallels Haraway's own description of a (possible) cyborg world as the "final imposition of a grid of control on the planet" (Haraway, 1991, p. 154). However, Sandoval's "grid" is mobile and responsive, demanding an increased vigilance on the part of the theorist. The "horizontalizing" of power can lead to the same fractures and tensions in feminism that Haraway discusses. Sandoval's answer is to explicitly "advance the possibility of connection, of a 'coalitional consciousness' 
in cultural studies across racialized, sexualized, genderized theoretical domains...[which] requires a trespassing operation" (p. 79). Such a connection would open a space to practice what she terms a methodology of the oppressed.

Secondly, Sandoval's methodology of the oppressed deeply intertwines with an ethic and belief in "love as social movement" (p. 184). Drawing on the Foucauldian concept of desire, Sandoval describes love as a "hermeneutic, a set of practices and procedures that can transit all citizen-subjects, regardless of social class, toward a differential mode of consciousness and its accompanying technologies of method and social movement" (p. 140). Sandoval's insistence on desire and affect as a deeply moving force for action and coalition addresses an element that is lacking in Haraway's figure of the cyborg. Indeed, such a concept of desire emphasizes the cyborg's ability to engage while preserving difference.

Aimee Carillo Rowe (2005) emphasizes the role that desire, love and "affective investment" have in power relations. Rowe draws on Sandoval's methodology for the oppressed as a way to construct the concept of "differential belonging," which she encourages as a "tactical maneuvering across resistive communities" (p. 15). Again, the cyborg figure is capable of enacting "differential belonging," is built in such a way that its only means of belonging is differential. The cyborg is well able to engage in this way; however, there seems to be a lack of impetus for the figure to do so.

The cyborg as a figure offers substantial opportunity for poststructuralist feminists to revision the world. Its commitment to partiality and its flexibility make it capable of enacting widely varied connections. Such connections preserve the differences of those involved; the cyborg need not appeal to holisms, origins or essentialized likenesses for such connections. As Wolmark (1999) summarizes, cyborg politics are "necessarily based on the possibility that new and strategic alliances can be forged between unexpected groups, no matter how partial or contradictory those alliances may be" (p. 4). Yet how can we avoid feeble alliances, tenuously and temporarily built? In other words, how can the cyborg figure engage ethically in transnational coalitions with feminists invested in the material realities of specific times and places? If we are to use the cyborg as a figure through which to understand self-technology relationships, and in turn our relationships with knowledge production and power, we should encourage the cyborg figure to invest emotionally and intellectually in connections, and to desire such connections be beneficial at the local level. The connections do not require permanence, but rather an ethic, a guiding morality that recognizes that though unfettered, theorists should deploy the figure of the cyborg with the same level of care and self-reflection most feminist methodologies require.

\section{An ethic of response-ability}

One way to accomplish these goals is to envision an ethical "prosthesis" for the figure of the cyborg, something to "outfit" the cyborg figure for such connections. Imagining such a prosthesis as an optional attachment for the cyborg figure enables the cyborg to have an attachment for attachment, a means for engaging in connections ethically and responsibly. It serves to enhance the humanity of the cyborg through technology, rather than the diminishing or erasing humanity and human affect.

Returning to the work of Rowe (2005) and Sandoval (2000), we find affective desire as playing a central role in the construction of the self-world relationship. Rowe develops what she calls a "politics of relation," a play on Rich's 1984 "politics of location." Rowe argues that our affective ties are a source of power; those things that we choose to care about become stronger through our affect. A politics of location emphasizes the situatedness and specificity 
of individuals and positions. Yet a politics of relation recognizes that the specificity of the individual is not the primary motivation in politics, but rather our affective ties.

Mary Strine (1989) discusses the "complex interconnections between voice and value" (p. 4) in Adrienne Rich's poetry, and terms Rich's later work an exercise in personal "responseability" (p. 33). The term seems a particularly apt one for preserving the impetus toward political efficacy while maintaining the importance of accountability. Strine argues that:

[P] ersonal response-ability replaces systematic analysis as the unifying strategy of poetic self-enactment. Two self-directed questions frame the exploratory process now: "With whom do you believe your lot is cast?/From where does your strength come?"...More importantly, they signal a shift in emphasis from the problems of the feminine self-identity per se to constructive dialogic engagement with the social and historical circumstances from which that self-identity emerges (p. 33, italicized lines from Rich, as quoted by Strine).

The guiding questions, "With whom do you believe your lot is cast? / From where does your strength come?" are the foundations of the ethic of response-ability. The question "With whom do you believe your lot is cast?" can be updated for the here and now, demanding that one acknowledge the realities of globalization and the flow of capital, labor, information and people; that is, one must acknowledge the lives and stakes of previously disparate peoples and places as now intersecting in new and multiplying ways. The question "From where does your strength come?" stresses a personal accounting of attachments, an awareness of our own biases, alliances and history. Even a cyborg, as removed from history and without debt as Haraway constructs it, is still - by definition - a hybrid of human and machine. Thus, its human elements (and our own, should we use the cyborg figure as a means to envision alternate forms of knowledge production and subjectivity) are never devoid of some bias, some history. To pretend otherwise is to enter into dangerous territory indeed.

These two questions create an intersubjective and iterative process of experience, one of self-reaching-out and the other of self-made-available to the world. Though Strine terms the phrase "response-ability," and quotes the two lines from Rich's poetry, she does not discuss response-ability as a process of repeating these two questions. The ethic of response-ability takes the local as its starting point, for it is in the local that we respond to the world, that we live our sphere of ability. Any entity engages with the world from someplace, and while our technological reach may be global, we still inhabit the local.

Take, for instance, our contemporary communication technologies like the Internet. Those of us with material and knowledge abilities can access a global network, we can connect with others across the world, and we can participate in transnational flows of information, money and labor. Yet we access these technologies with our bodies, situated materially in a location. In such a location, we have experiences and interactions aside from those we have in the global network. The hardware we use to access the Internet is produced in a place, and needs to be physically available to us. It may be seductive to think of ourselves as entering into a nonmaterial space, but such an idea "draws on an abstract, disembodied concept of the individual that is far removed from the concrete day-to-day practices which make individuality and forms of togetherness possible in the first place" (Kelemen and Smith, 2001, p. 377).

Thus, an ethic of response-ability foregrounds the role of the local, demanding an account from within, from the sphere of ability. Likewise, the ethic's outward-focused element, 'with whom do you believe your lot is cast?', emphasizes the material indebtedness and interconnectedness of individuals and groups. Even if we adopt the solitary-minded cyborg as a figure through which to envision new forms of knowledge production, any alternate forms of understanding the world must address the differential needs and experiences of various groups and individuals, and recognize the impact of globalization as non-uniform (see Hegde, 1998; 
Shome and Hegde, 2002). An ethic of response-ability offers an ongoing process that may produce and maintain productive feminist alliances.

\section{Choosing to connect}

The cyborg is essentially permeable. Haraway constructs the figure as blurring the boundaries between organic and inorganic, a figure that is partial and unfinished, constantly changing and adjusting. Incorporating an ethic of response-ability in such a figure is, I believe, consistent with the aims and purposes of the cyborg as Haraway originally understood it. Such an ethic updates the cyborg for more productive coalition building in our increasingly complex global environment. It furthers Sandoval's rehabilitation of Haraway's cyborg, and encourages the cyborg to engage in an ethical, iterative process of connection.

It is important to note that the ethic of responsibility is an optional attachment for the figure of the cyborg. Necessitating such a prosthesis negates the cyborg's careful commitment to partiality, as well as undermining the feminist goal of promoting individual choice. As noted earlier, even the choice to use the prosthesis does not "complete" the cyborg as a construct; there remains room to change, grow, become and connect in new ways. Why would a theorist interested in the cyborg figure make the choice to use the prosthesis?

The most important reason for a theorist to "outfit" the cyborg with an ethic of responseability is that it multiplies the cyborg figuration's possibilities for political efficacy. If we align and ally the cyborg and its associated technofeminisms with transnational feminisms, we can build global coalitions that have a greater ability to respond to our contemporary context. With such an ethic of response-ability, we can better understand and shape the material realities of growing technology use to benefit women and further poststructuralist feminist goals of inclusion. The precarious, shifting and globalized world is deeply resonant in the rapid, everchanging actualities of technology. Technofeminism has much to gain from adopting an ethic of response-ability, and deepening its affective ties.

Future scholarship should investigate the potential repercussions of incorporating cyborg scholarship into transnational alliances. For instance, once transnational feminists ally with poststructuralist feminists who are using the cyborg as a figuration, what material effects might there be on the lived experiences of those in the Global North and the Global South? In particular, future research should investigate the ways in which such alliances may bridge the gap between theory and activism. Though the optional attachment of the ethic of responseability outfits the cyborg for careful coalition building, the fruitfulness of such alliances remains an unanswered question.

\section{References}

Braidotti, R. (1994). Nomadic Subjects: Embodiment and Sexual Difference in Contemporary Feminist Theory. New York: Columbia University Press.

Butler, J. (1990). Gender trouble. New York: Routledge.

Foucault, M. (1972). The archeology of knowledge and the discourse on language. New York: Pantheon.

Foucault, M. (1980). Power/knowledge. New York: Pantheon.

Haraway, D. (2008). When species meet. Minneapolis, MN: University of Minnesota Press.

Haraway, D. (1999). The promises of monsters: A regenerative politics for inappropriate/d Others. In J. Wolmark (Ed.). Cybersexualities: A reader on feminist theory, cyborgs and cyberspace (pp. 314-366). Edinburgh, U.K.: Edinburgh University Press. 
Haraway, D. (1995) Cyborgs and symbionts: Living together in the New World Order. In C.H. Gray (Ed) Cyborg Handbook (pp. xi-xx). New York: Routledge.

Haraway, D. (1991). A Cyborg Manifesto: Science, Technology, and the Socialist Feminism in the Late Twentieth Century. Simians, Cyborgs and Women: The Reinvention of Nature (pp. 149-181).

Hay, P. (2006). A phenomenology of islands. Island Studies Journal, 1(1), 19-42.

Hayles, N. K. (1999). How we became posthuman. Chicago, IL: University of Chicago Press. Hegde, R. (1998). A view from elsewhere: Locating difference and the politics of representation from a transnational feminist perspective. Communication Theory, 8(3), 271-297. CrossRef

Hicks, L. (1990). A feminist analysis of empowerment and community in art education. Studies in Art Education, 32(1), 36-46. CrossRef

Kelemen, M. and Smith, W. (2001) Community and its 'virtual' promises: A critique of cyberlibertarian rhetoric. Information, Communication \& Society 4(3), 370-387. CrossRef

Lyotard, J. (1989). The postmodern condition. Minneapolis, MN: University of Minnesota Press.

Puar, J.K. (2012). "'I Would Rather Be A Cyborg Than a Goddess': Becoming-Intersectional of Assemblage Theory," PhiloSOPHIA: A Journal of Feminist Philosophy, 2(1), 4966.

Rich, A. (1984/2003). Notes toward a politics of location. In C.R. McCann \& S.K. Kim (Eds.), Feminist Theory Reader: Local and Global Perspectives, (pp. 447-459). New York: Routledge.

Rich, A. (2003). What is found there. New York: WW Norton \& Co.

Rowe, A. C. (2005). Be longing: Toward a feminist politics of relation. NWSA Journal 17(2), $15-46$.

Sandoval, C. (2000). Methodology of the oppressed. Minneapolis, MN: University of Minnesota Press.

Sandoval, C. (1995). New science: Cyborg feminism and the methodology of the oppressed in C.H. Gray (Ed.), Cyborg Handbook (pp. 407-422). New York: Routledge.

Shome, R. and R. Hegde. (2002). Postcolonial approaches to communication: Charting the terrain, engaging the intersections. Communication Theory, 12(3), 249-270. CrossRef

Strine, M.S. (1989). The politics of asking women's questions: Voice and value in the poetry of Adrienne Rich. Text and Performance Quarterly, 1, 24-41. CrossRef

Sunden, J. (2001). What happened to difference in cyberspace? The (re)turn of the she-cyborg. Feminist Media Studies, 1(2), 215-232. CrossRef

Weedon, C. (1999). Feminism, theory and the politics of difference. Cambridge, MA: Blackwell Publishers.

Weedon, C. (1997). Feminist practice and poststructuralist theory. Cambridge, MA: Blackwell Publishers.

Wolmark, J. (Ed.). (1999). Cybersexualities: A reader on feminist theory, cyborgs and cyberspace. Edinburgh, U.K.: Edinburgh University Press.

Yeoh, B.S.A. (2005). Transnational mobilities and challenges. In L. Nelson and J. Seager (Eds.), A Companion to Feminist Geography, (pp. 60-73). Oxford: Blackwell. 